\title{
On a Set of Proper Names in the Tradition
}

\author{
Sergei G. Proskurin ${ }^{a, b}$ \\ and Anna V. Proskurina ${ }^{\mathrm{b} *}$ \\ a Novosibirsk State University \\ 2 Pirogov Str., Novosibirsk, 630090, Russia \\ ${ }^{b}$ Novosibirsk State Technical University \\ 20 Marx, Novosibirsk, 630073, Russia
}

Received 04.05.2017, received in revised form 28.06.2017, accepted 03.07.2017

The current article deals with the question of a set of proper names in the tradition. The article shows that a set of proper names can be organized on the basis of alliteration and can be transferred from a generation to a generation. There are some correlations between the proper names and names of kingdoms. It is history of Germanic tribes. In the article the issues of syntagmatics and paradigmatics of proper names in genealogies of Anglo-Saxon kings are considered. The authors emphasize the complex type of nomination in Anglo-Saxon tradition when not only the tradition of inheritance, that is the succession in the paradigmatics of the king's name, but also the observance of rules of identity at the level of correlation of name, on the one hand, and ethnonym or name of kingdom, on the other hand, were taken into account.

Keywords: a set of proper names, correlation, alliteration, Germanic tribes.

The research was funded by grant no. 14-28-00130 of the Russian Science Foundation. The project is carried out at the Institute of Linguistics, Russian Academy of Sciences.

DOI: 10.17516/1997-1370-0102.

Research area: philology.

Names inspire people to the idea of something that is not destined to perish, names are very suitable in order to excite in each generation or family the desire to extend their existence; there are peoples in which names define generations or families; there are also peoples whose names distinguish only individuals (See Montesquieu "The Spirit of the Laws").

The stratification in the naming of entities to common nouns and proper names is sometimes illustrated as follows. So, if the named tiger isn't different from another animal, then the latter can be called a tiger. However, if it is known that the name of one of these tigers is Witchgren, then it does not follow that the name of the second tiger is also Witchgren. The adoption of such a method of naming, or the code of the nominal name for the naming of the second individual, is false, since it contradicts the rule of the individual's own name, characterized by selective point. In other words, the proper names clearly demonstrate the situation in which the code is referred to itself

(C) Siberian Federal University. All rights reserved

* Corresponding author E-mail address: s.proskurin@mail.ru; a.vyacheslavovna@gmail.com 
(code referring to code) (Jacobson, 1972:96), but within the confines of closed collectives.

The name is a rigid designator; this is a term which denotes the same individual in any of the possible worlds. In other words, the name refers to a certain human being in any of the possible cases in which we can speak about this individual at all, and the facts of the biography have nothing to do with it. The name's reference is actually fixed at the moment when parents point a finger at their baby who, according to their wishes, will bear this name, or at any other time when a name is assigned to a person. It continues to point to a person throughout his/her life and afterwards, thanks to a chain of transmissions in which a person who knows this name uses in the presence of another person who is going to use it in the same way (Pinker, 2013: 345-346). Thus, the name to some extent is a representative of a person in an ethnos. Sometimes this representation of the name was accompanied by certain rules for handling the name.

There are, as it were, primary and secondary names. The first are divine deeds, and the latter are the result of people's naming. In Indo-European linguistics there was an idea of the language of people and gods. And this was recognized as an ancient tradition at a very deep theoretical level. Subsequently, the function of the creator and the caller is reinterpreted and eventually considered independently.

In a number of the oldest Indo-European traditions (Ancient Indian, Ancient Greek, Ancient Iranian, etc.), a special institution of naming emerges, whose function is to answer for the correctness of naming certain true causes of things-entities.

Such an institute of onomates (Old Greek

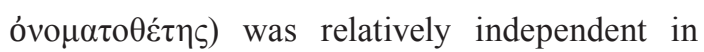
its activity from the creators of things and was oriented solely to finding the essence of a name and determining the correspondence of a name and a thing, i.e. to their naming, nomination. The professionalization of such onomates was confirmed by early information relating to the ancient Greek school of the Pythagoreans. Similar institutions have been recorded in a number of other traditions of the Indo-European area: Ancient Iranian, Ancient Indian, Ancient German, etc. The onomastic act, equivalent to the process of creation, was the first comprehension of the complex unity of the name and object.

The name was understood not as a conditional name of an object, but as something that already contains the rules for dealing with a named thing or an explanation of the behavior of the named object. If, for example, a person was called, then, as expected, he had to behave in accordance with his/her name. The name displayed some properties of his/her appearance, character, activity or profession. The same is true for things whose name expresses their essential properties, recalls the rules for dealing with them. Accordingly, the primary perception of the essence of the name was imbued with a conditional etymological nature. The etymologization of the name in the first studies on the history of the words of Ancient Greece and Rome was essentially a continuation of the oldest tradition of searching for the essence of the name.

In the mythopoetic tradition, we meet with a contrasting situation in relation to the one, which was described by K. Marx in the context of his political economics. The name of a thing has nothing to do with its nature. I absolutely do not know anything about this person, if I only know that his name is Jacob (Marx, Engels, vol.23, 110). However, people outside of science at all times argued in exactly the opposite way, believing that knowledge of the name opens the way to the essence (See Stepanov, 1985: 13). So, A.Ya. Gurevich, on the example of the Scandinavian sagas, showed that the dating of described events (in spite of a large number of 
indications of the time) is almost impossible due to the lack of connection with the Christian or other chronology. Temporal landmarks were names proper. In other words, time was correlated and organized within the life and government of the supreme ruler; and in this case his actions were as temporal landmarks (Gurevich 1990: 76, 78). For the Scandinavians of that era, it was more important to know a person's pedigree than its coordinates on a chronological scale. If the origin and place of residence of a person were known, his relatives, marriages with other families, friendly ties were indicated, then enough was said about him so that a medieval person with proper distinctness localized him in his mind and could follow the events of his life without asking, for instance, in what year from the Nativity of Christ, these events took place (Gurevich 1990: 76-77).

The idea of the direct correspondence of a name and a denoter, the interpretation of the name of one's own as an alter ego of an individual is the traditional historical concept of nāmarupa (name and form), based on the name for real connections. In this case, it seems to be a successful comparison of Jan Gonda. He wrote, that the relationship between the name and its bearer can be compared with the shadow and the person who throws it away (Gonda, 1970:8) (See also Toporova, 1996:7).

Before the appearance of alphabets, the forms of cultural memory functioned - the identity of the individual was identical with the identity of the ethnos. It is possible that the need for codification through sound recording was the forerunner of the emergence of alphabets, inasmuch as the semiotics of sound recording is a preliminary stage of search for saving of speech. So, for the Anglo-Saxon grandees, who had Celtic names, their names were consonant with Cymro's ethnonym Welshman: Caedwalla, Caedda, Cedd, Ceawlin, Cerdic, Cumbra (Crystall, 2004:32).
For example, the onomasticon of the Anglo-Saxon nobility is alliterating with the ethnonym Welshman, the choice of which was not accidental (Hereinafter the contexts are given by: The Anglo-Saxon Chronicle: An Electronic Edition (Vol 5) literary edition): 519 Her Herdic 7 Cynric: Westsexena rice onfengun on py ilcan geare hie fuhton wip Brettas pær mon nu nemnep Cerdicesford: 7 sippan ricsadan Westsexana cynebearn of pan dæge ( This year Cerdic and Cynric obtained the kingdom of the WestSaxons; and the same year they fought against the Britons where is is now named Cerdicsford). Probably, as it can be concluded from the context, it was a question of ethnic mixing of the Germans with the Celts. 560 Her Ceawlin feng to rice on Wesseaxum $<\ldots>$ (This year Ceawlin succeeded to the kingdom of the West-Saxons $<$... $>$ ); $643 \mathrm{Her}$ Cenwalh feng to Wesseaxna rice 7 heold .xxxi. Wintra $<$... $>$ (This year Cenwalh succeeded to the kingdom of the West-Saxons, and held it thirtyone years); $709<\ldots>7$ Ceolred feng to Myrcna rice $<_{\ldots} . .<(<\ldots>$ and king Ceolred succeeded to the kingdom of the Mercians $<$... $>$ ).

It is obvious that in science there is a connection between proper names and eponyms. Claude Lévi-Strauss once said, that individual names depend on the same system as the collective names which were previously studied, and that through them it is possible to move by means of transformations from the horizon of individuation to the horizon of the most general categories. Indeed, each clan or subclan possesses a certain number of names that are carried to its members, and since the individual is a part of the group, the individual name is a part of the collective name (Levi-Strauss, 2008:361).

According to the list of names (an alliterative list of names) of Anglo-Saxon kings, the alliterations between the king's name and the name of the kingdom are maintained in three kingdoms (Ēast Engla Rīce, Ēast Seaxna Rīce, Westseaxna 
Rīce): Anna, Aethelhere, Aldulf $<$... $>$ - East Engla Rīce; Seaxnete, Swaeppa, Sigefugel $<\ldots>$ - Ēast Seaxna Rīce; Aedmund, Aelfred, Aelfgiva <...> - Westseaxna Rīce. In other lists, homogeneity of names correlates with the name of the kingdom by a type. Such names performed a function of a sense of difference, it was possible to determine what kind of kingdom it was. For example, if a name starts with $E$, it indicates that the kingdom is Cent (Emme, Eormenred, Ermenburga $<\ldots>$ ), if $C$ - Mierce (Cnebba, Cynewald, Creoda), if $A$ - Norpanhymbra (Alhfrith, Aedryht, Aethelwold $<\ldots>$ ).

The possibility of linking genealogy in the sequence with alliteration is important from the point of view of the structure of the text: syntagmatics and paradigmatics. The sequence of names in the tradition formed syntagms that interacted with ethnonyms in paradigmatic, using alliteration to the same letter.

So, in Northumbria lived Angles. Perhaps this fact influenced the names of the kings which start with $A$, and these names are connected in paradigmatic with the name of the ethnos Angle. However, this remains a historical hypothesis. The lists themselves played a historical role, that is, they were a living history of the Anglo-Saxon kingdoms, and their function was ensured by the transmission of information from generation to generation. This is the meaning of the AngloSaxon tradition (See: Proskurin, Proskurina, 2014).

In any case, the paradigmatic transfer of phonetic markers in the names of the AngloSaxon grandees in diachrony correlates with the names of the collectives. This type of interaction is adjacent to the traditional type of connection, the proper name - totem. It is also likely that the Scandinavian roots of the correlation of the names Rhos - Rurik could serve as a factor that influenced the choice of the ethnonym Rus. From the modern point of view, as academician Yu.S. Stepanov writes, there is, however, no need to regard this name of the Eastern Slavs as the one given by the Germans. Most likely, the semiotic parallel of the German name Rurik and the ethnonym Rhos, that is, the tribe of the Swedes, served as a factor that influenced the choice of the term Rus, which originally associated with the Northern Novgorod Center. Gradually it moved to the south and became entrenched in the southern Kiev center, gradually turning into an ethnic term to denote the entire population of this land and the state term (Stepanov, 2004:152). As a relic of the German semiotic rule, the proper name and the name of the tribe in Rus, the correlation of the name of the Rurik dynasty with the name of the state itself remains.

A set of names within the Anglo-Saxon Chronicle is associated with the choice of syntactic constructions in the translation of archaic texts. Let us turn again to the excerpts of the Anglo-Saxon Chronicle. The names here are used within the framework of the formula Her sum. (on)feng to rice, there are names of the Roman emperors: 70 Her Uespassianus onfeng rice (This year Vespasian obtained the empire). In the excerpt dated 81 year, the formula Her sum. (on)feng to rice begins to re-grow with new facts, namely, the name of the heir is given and a brief information about him is given too, so here we register the series with an increasing specification
Anna
Aethelhere
Aldulf
Aelfwold
Aethelbert
Aethelburn
Aetheldryth

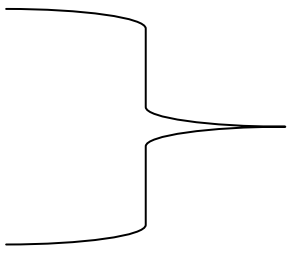

Ēast Engla Rīce

(The Kingdom of East Anglia) 


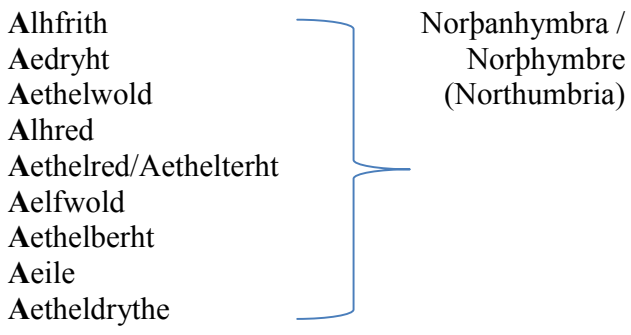

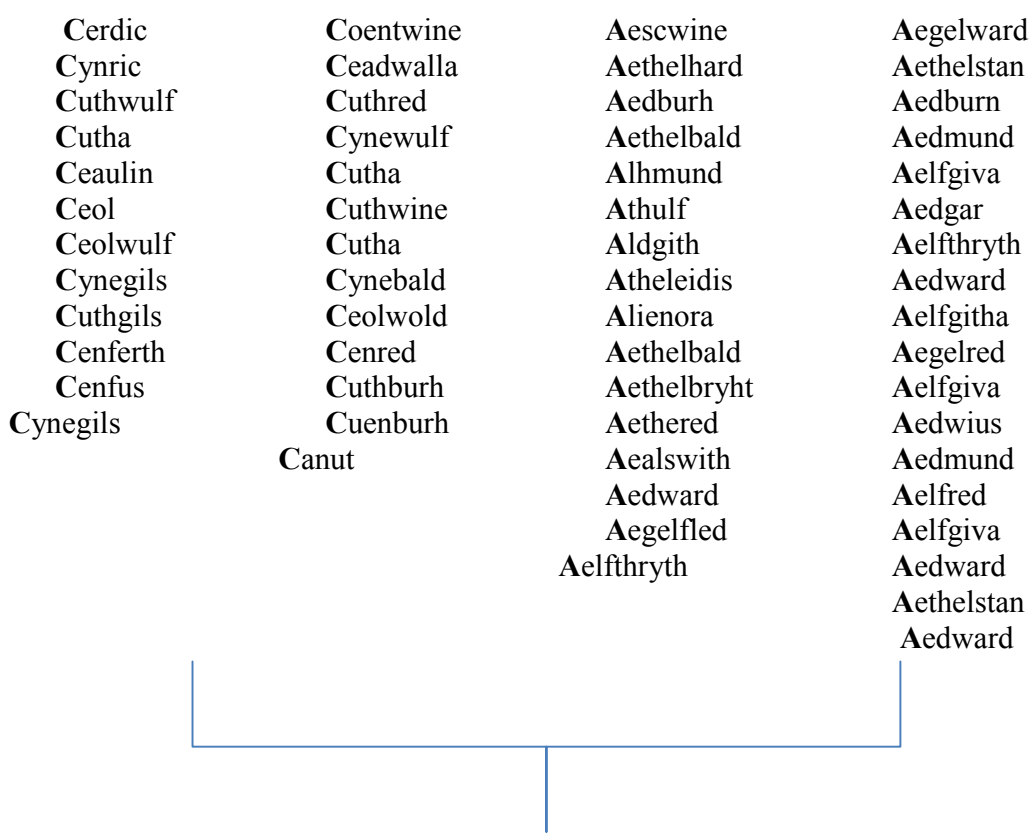

Westseaxna Rīce (The Kingdom of Wessex)

Seaxnete

Swaeppa

Sigefugel

Sledda

Saeberht

Saexraed

Saexn

Sigeferth

Seleferth

Sigebald

Swithelm

Saebbi

Sighere

Sigheard

Saelread

Swithhaed

Sigeric

Sigeraed

Ēast Seaxna Rīce (The Kingdom of Essex or Kingdom of the East Saxons) 
towards earlier excerpts: 81 Her feng Titus to rice, se pe sæde pæt he pone dæg forlure pe he naht to gode on ne dyde (This year Titus succeeded to the empire, he who said that he had lost the day on which he had done no good). In the excerpts of 84 and 155 years the names of the heirs are fixed again, the information goes to a decline (rows with descending detail in relation to the early excerpts): 84 Her Domitianus Tites bropor feng to rice (This year Domitian, the brother of Titus, succeeded to the empire); $155 \mathrm{Her}$ Marcus Antonius 7 Aurelius his broðer fengon to rice (This year Marc Antony and his brother Marcus Aurelius succeeded to the empire); 423 Her Herodosius se gingra feng to rice (This year Theodosius the younger succeeded to the empire); 449 Her Mauricius 7 Ualentines onfengon rice 7 ricsodon .vii. Winter $<\ldots>$ (This year Martianus and Valentinus succeeded to the empire, and reigned seven years); 583 Her Mauricius feng to Romana rice (This year Mauricius succeeded to the empire of the Romans). For the contemporaries of these excerpts, the Latin onmasticon was without a transparent internal form. Such excerpts form a serious early layer of chronicles. The communicative strategy for translating the marked proposals of the Roman period is based on the information transfer factor. The role of Latin proper names is that they influence the choice of the term noun translation of rice. If in the formula Her sum. (on)feng to rice ( Here someone inherited the throne (kingdom, state, empire)) Roman name is used, then rice is translated as throne (empire).

The communicative goal of the utterance influences the information transfer factor from a generation to a generation. Communicative strategies are changed significantly when the analyzed formula begins to be used in relation to the German period of rule on the island of Britain: 674 Herfeng Æscwine to rice on Wesseaxum, se wes Cenfusing, Cenfus Cenferting, Cenfer
$\mathrm{Cu}$ gilsing, Cupgils Ceolwulfing, Ceolwulf Cynricing, Cynric Cerdicing (This year Aescwin succeeded to the kingdom of West-Saxons; he was the son of Cenfus, Cenfus of Cenferth, Cenferth of Cuthgils, Cuthgils of Ceolwulf, Ceolwulf of Cynric, Cynric of Cerdic). Here rice begins to be used in the meaning of kingdom, and the name itself is represented by names with a transparent inner form, understandable to the Anglo-Saxons.

Homogeneity of the naming of kings is associated with the rule of thula. The alliterative names of rulers are determined by the oral stage of the existence of culture, when genealogical sequences were named in the same way, in order to preserve historical information about the past in the historical memory of Anglo-Saxon tribes.

Using the phonetic and frequency analysis of anthroponyms helps to identify and describe a new naming principle which is phonetic one. This naming principle distinguishes alliteration as an Old German identity. It is preserved in the collective memory thanks to a subconscious choice of proper names for their sound formation. On the material of a set proper names in the city of Winchester, the initial and final sounds / letters were singled out, which among the male and female proper names received maximum distribution. Namely, the final sound $a$ among the female names had a visible advantage, as it was present in more than 40 proper names of own of the total 74 (Khotskina, 2014:18).

The idea of transference of information is reflected in ancient Germanic poetic tradition, i.e. in the genre of thula. The structure of thula is based on the idea of cycle, which is defined by longevity of a human life. The communicative task which is realized in the thula in the form of a chant creates a support for the transmission of information. Assonance (alliteration) in the next thula, which is adjacent to the analyzed formula, indicates the dynastic cycles of Anglo- 
Saxon kings: 738 Her Eadbryht Eating, Eata Leodwalding, feng to Nor'anhymbra rice 7 heold .xxi. Wintra $<\ldots>$ (This year Eadbriht the son of Eata, the son of Leodwald, succeeded to the kingdom of Northumbria an reigned 21 years $<\ldots>$ ); 866 Her feng Ępered Ępelbryhtes bropur to Wesseaxna rice $<\ldots>$ (Aethered, the brother of king Aethelbert, succeeded to the kingdom of the West Saxons $<\ldots$... $)$.

L.G. Vikulova and E.G. Vasilieva noted that onomastic aspect in the early medieval picture of the world was given a special place, because there was a connection between the name of the ruler and differentiation among relatives. On the example of choosing the names of the Merovingian dynasties, the principle of variation of elements with the principle of hereditary transmission on the basis of alliteration was shown. So, the roots of chold, mer mech, which make up the names of Chlodio and Mérovée, the real or supposed ancestors of Clovis, the authors find in the names of Ingomer, Clodomir, Clothaire, while child from Childéric is included in the names Lantechild and Childebert (Vikulova, Vasilyeva 2015: 61).

The noted formula Her sum. (on)feng to rice forms a cluster with another formula Sum. Forpferde (Someone died) due to a communicative extension that facilitates the transmission as a whole: Her sum. Forpferde, 7 sum. (On) feng to rice (Here someone died and someone inherited the kingdom). German names of the formula obey the idea of the cycle that forms the dynastic period of the thula during the significant period of the Middle Ages: 819 (actually 821) Her Cenwulf Miercna cygnen foreferde, 7 Ceolwulf feng to rice $<_{\text {... }}>$ (This year Cenwulf king of the Mercians died, and Ceolwulf succeeded to the kingdom<...>); 940 Her Æpelstan cyning forðferde on Gleaweceastre on. Vi. Kalendas Nouembris, ymb .xl. Wintra butan anre nihte pæs pe Ælfred cyning forðferde, 7 Eadmund æpeling feng to rice, 7 he wæs pa .xviii. Wintre $<\ldots>$ (This year king Aethelstan died, at Gloucester, on the $6^{\text {th }}$ of the kalendas of November, about forty-one years, except one day, after king Aelfred died. And Eadmund the etheling, his brother, succeeded to the kingdom, and he was then eighteen years of age $<\ldots>$ ); 958 Her forðferde Eadwig cyng on kalendas Octobris, 7 Eadgar his broðor feng to rice (This year died king Eadway, on the kalendas of October; and Eadgard, his brother, succeeded to the kingdom $<$...>).

As O. V. Khotskina points out, there are cycles of naming in the Old Germanic tradition. Thus, a cycle with a darkened inner form - the cycle of naming, for example, the Latin name, is replaced by a cycle of naming with a transparent internal form - an ancient Germanic name (Khotskina, 2014).

Further, even the non-expanded cycles in the Old Germanic names, which are consist of two rulers: the deceased and the heir to the throne, obey the noted rule of thula and alliterate in the prosaic text: 924 Her Ædward cygning forðferde, 7 Æpelstan his sunu feng to rice (This year king Edward died, and Aethelstan his son succeeded to the kingdom); 946 Her Eadmund cyning forðferde on Sancte Agustinus mæssedæge $<\ldots>7$ ba æfter him feng Eadred æpeling his bropor to rice, 7 gerad pa eall Norðhymbra land him to gewealde. 7 pa Scottas him sealdon apas pæt hi eall woldon pæt he wolde (This year king Eadmund died, on St. Augustine's mass-day $<$... $>$ And then after him his brother Eadred the etheling succeeded to the kingdom, and subdued all Northumberland under his power: and the Scots gave him oaths, that they would all that he would).

However, sometimes these rules are not respected, which is also worthy of attention. Perhaps this is due to the violation of the dynastic cycle: 675 Her $<\ldots>7$ py ilcan geare Wulfhere forpferde, 7 Eqpelręd feng to rice (This year <...> and the same year Wulfhere died, and Aethelred succeeded to the kingdom). 
The change of the dynastic cycle is often connected with the rule of changing the alliteration of the proper name: 634 Her feng to Dearne rice Osric pone Paulinus ær gefullode, se wæs Ælfrices sunu Ædwines federan, 7 to Bærnicum feng Æðelfriðes sunu Eanfrið $<\ldots>$ (This year Osric, whom Paulinus had formely baptized, succeeded to the kingdom of Deira; he was the son of Aelfric, Aedwin's uncle. And Eanfrith the son of Aethelfrith

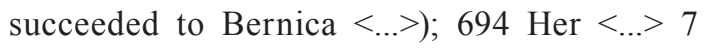
Wihtred feng to Cantwara rice, 7 heold .xxxiii. Wintra; Se Wihtred was Ecgbryhting, Ecgbryht Arcenbryhting, Erconbryht Eadbalding, Eadbald Epelbryhting (This year <...> And
Wihtred succeeded to the kingdom of the Kentish-men, and held it thirty-three years. Wihtred was the son of Ecgbryht, Ecgbryht of Erconbryht, Erconbryht of Eadbald, Eadbald of Aethelbryht).

Thus, there is a correlation between a set of proper names and names with reference to the genre peculiarity of translations of medieval texts. The choice of the Latin name for the emperors differs by a special entry in the texts in comparison with the entries of names of the German rulers. Names simply form a grid of values in translations. Therefore, it can be concluded that the names and syntax are closely related.

\section{References}

Vikulova, L.G., Vasil'eva E.G. (2015) Vybor imeni kak instrument ukrepleniya dinasticheskoy vlasti v rannem Srednevekov'e (Frantsiya, $V-X v$ v.) [The name choice as an instrument to reinforce the dynastic power in the Early Middle Ages (France, V-X cc.)] In: Verkhnevolzh. filol. Vestn [Verhnevolzhski philological Bulletin] № 2. - P. 58-64.

Gurevich, A.Ya. (1990) Srednevekovoy mir: kul'tura bezmolvstvuyushchego bol'shinstva [The Medival World: The Culture of the Silent Majority]. Moscow: Iskusstvo.

Marks, K., Engel's, F. (1960) Sochinenia [Writings] 2-e izd., t.23. Moscow: Politizdat.

Pinker, S. (2013) Substantsiya myshleniya: Yazyk kak okno v chelovecheskuyu prirodu. Per. s angl. [The Stuff of Thought: Language as a Window into Human Nature] Moscow: Knizhnyy dom «LIBROKOM».

Proskurin, S.G., Proskurina A.V. (2014) Kommunikativnoe rasshirenie formuly [The communicative extention of a formula]. In: Evropeyskiy zhurnal sotsial'nykh nauk [European Social Science Journal] № 8 - 1 (47). - P. 252-257.

Stepanov, Yu.S. (1985) V trekhmernom prostranstve yazyka. Semioticheskie problemy lingvistiki, filosofi, iskusstva [In three-dimensional space of language. Semiotic problems of linguistics, philosophy, art]. Moscow.

Toporova, T.V. (1996) Kul'tura verkale yazyka: drevnegermanskie dvulichnye imena sobstvennye [Culture in the mirror of the language: two-faced old Germanic proper names]. Moscow.

Khotskina, O.V. (2014) Semiologicheskoe opisanie srednevekovogo antroponimikona (na materiale dannykh arkhiva goroda Vinchester v period X-XIV vekov) [Semiotic description of medieval antroponymycon (based on Winchester material X-XIV cc.)]. Abstract of Philology CSc. Diss. Barnaul.

Yakobson, R.O. (1972) Shiftery, glagol'nye kategorii i russkiy glagol [Shifters, verbal categories and Russian verb] In: Printsipy tipologicheskogo analiza yazykov razlichnogo stroya [Principles of the typological analysis of various system languages] Moscow: Nauka. P.95-113.

Crystal D. The Stories of English. London: Penguin books, 2004.

$$
-1068-
$$


Gonda J. Notes on names and the name of God in ancient India. Ltd, 1970.

Montesk'e «O dukhe zakonov» XXIII, IV [Electronic resource]. at: http://worldconstitutions. $\mathrm{ru} / \mathrm{p}=1166 \& \mathrm{page}=5$ (accede: $10.01 .2016 \mathrm{~g}$.).

The Anglo-Saxon Chronicle: An Electronic Edition (Vol 5) literary edition [Electronic resource]. -at: httpasc.jebbo.co.ukbb-L.html (accede: 10.01.2016 г.).

\title{
К вопросу функционирования именника
}

\section{в традиции}

\author{
С.Г. Проскурин ${ }^{\mathrm{a}, \tilde{0}}$, А.В. Проскурина ${ }^{\tilde{\sigma}}$ \\ ${ }^{a}$ Новосибирский национальный исследовательский \\ государственный университет \\ Россия, 630090, Новосибирск, ул. Пирогова, 2 \\ ${ }^{6}$ Новосибирский государственный технический \\ университет \\ Россия, 630073, Новосибирск, пр. К. Маркса, 20
}

\begin{abstract}
Настоящая статья имеет отношение к функиионированию именника в традици. Статья повествует, что именник может быть организован на базе аллитерации и передаваться из поколения в поколение. Существует определенная корреляиия между именами собственными королей и названиями королевств. Это история германских племен. Рассматриваются вопросы синтагматики и парадигматики имен собственных в генеалогиях англосаксонских королей. В статье подчеркивается комплексный характер именования в англосаксонской традииии, при котором учитывалась не только традиция наследования, т.е. преемственность в парадигматике имени короля, но и соблюдение правил идентичности на уровне корреляции имени, с одной стороны, и этнонима, или названия королевства, - с другой.
\end{abstract}

Ключевые слова: именник, корреляция, аллитерация, германские племена.

Исследование выполнено за счет гранта Российского научного фонда (проект №14-28-00130) в Институте языкознания РАН

Научная спеииальность: 10.00.00 - филологические науки. 